\title{
Female Directors, Mechanisms for Corporate Governance and Agency Cost
}

\author{
Farissha Alluwi ${ }^{\mathrm{a},}$ Anuar Sarun ${ }^{\mathrm{b}}$ \\ ${ }^{a}$ Faculty of Management and Economics, Universiti Pendidikan Sultan Idris, Malaysia, \\ sha_alluwi@yahoo.com \\ ${ }^{b}$ Faculty of Management and Economics, Universiti Pendidikan Sultan Idris, Malaysia, \\ anuar.sarun@fpe.upsi.edu.my
}

\begin{abstract}
This paper aims to investigate the effect of the presence of female board directors and corporate governance mechanisms on agency cost focusing on board of directors' and audit committee's characteristics. The samples used in this study consisted of 150 companies listed on Bursa Malaysia in trade and services sector from 2010 until 2013. The dependent variable in this research is agency cost. Based on the extensive literature review, this study applied two agency cost proxies, which are asset utilisation ratio (AUR) and expense ratio (ER). Meanwhile, there are seven independent variable which are female board directors, board size, CEO duality, independent directors, size of the audit committee, audit committee meeting and audit quality. Data was analysed using descriptive statistics, correlation analysis and linear regression. The empirical result reveals that female board directors, board size, CEO duality, independent directors, and audit quality have a significantly negative relationship with agency cost using asset utilisation ratio (AUR) as the proxy. Meanwhile, for expense ratio (ER) proxy, the result shows that female board directors, the size of the audit committee, and audit quality have a significantly negative relationship with agency cost. Besides that, with these research findings, the corporate companies could have a better and thorough understanding about corporate governance which would help them decrease their agency cost from time to time. The findings also could be used as the reference and guidance in establishing company policies or finance policies in decreasing the company's agency cost. Plus, these findings enrich the literature in corporate companies, thus help future researchers. Finally, the researcher presented some suggestions and recommendations for future studies to diversify the sectors of the selected companies so that the data obtained will be wider and larger. Besides, future researchers may extend the data period from four years up to 10 years.
\end{abstract}

\section{Keywords:}

Female directors, agency cost, asset utilisation ratio (AUR), expense ratio (ER)

\section{INTRODUCTION}

For over a decade, the issue of gender diversity in relation to the board of directors and top management has gained wide attention in the academic literature and newspapers. Recently, several studies (Thiruvadi \& Huang, 2011) had examined the glass ceiling issue that has prevented the progress of many qualified females in the organisation hierarchy due to several forms of discrimination. Moreover, juggling between family and career is an obstacle that hinders females from becoming leaders. Regarding the prediction of the future of females as leaders, the Director of the Female's Leadership Centre (PKW) stated that the goal would be achieved due to the active roles played by the leaders and non-governmental organisations (NGO) including associations and women organisations in various fields. Currently, more females have attained higher education, and they are not only knowledgeable but also more open-minded. Therefore, the current leadership needs to take a 
suitable approach to ensure that the future generation will be ready to assume the leadership role and develop themselves, family, society and organisation.

While the number of female directors on the corporate boards has seen an increasing trend in the recent years, it remains at a low level. Previous research (Carter et al., 2003) found that the presence of at least one female on the board who brings success to the company is somewhat surprising. The reason is that the number has not been increasing significantly, especially following corporate scandals and the newly established regulatory actions.

In Malaysia, as reported in Berita Harian newspaper on 28 Jun 2011, the corporate sector and statutory institutions are required to have at least $30 \%$ women at the decision-making level, in line with the recognition by the government that women play an important role in the development and well-being of the country. This policy was decided upon on 24 Jun 2011, and it allows for a transition period of five years until 2016 for the corporate sector and statutory institutions to increase the number of women on the board and appoint them to the top positions in their respective organisations.

When the Prime Minister of Malaysia Dato' Seri Najib announced the policy, he said that the five years transition period is reasonable and he hoped that it would be considered as a notice to the relevant parties to take proactive and progressive actions so that the goal that had been set could be achieved. The policy will also serve as a catalyst towards achieving gender equity in the corporate sector.

Nevertheless, the extent of the female directors' capability in monitoring the board effectively and the effect of female directors' presence towards agency cost are still uncertain. In other words, the effect of the presence of female directors towards the firm's agency cost has not been ascertained.

The appointment of females on the board will incur various other costs, and these costs will be borne by the companies concerned. As a result of this policy, companies have to appoint new female directors, and it may take considerable time to find new female directors who are suitable for the role. Besides, the remuneration that will be paid to the newly appointed female directors will result in an increase in the company's cost. Therefore, companies need to know whether the appointment of female directors will be worthwhile by looking at the female directors' ability to monitor the agency cost.

\section{LITERATURE REVIEW}

\section{Female directors and agency cost}

A study on female directors and agency cost had been conducted by Nirosha and Stuart (2013). The study examined the relationship between female directors and the financial performance of companies and the agency cost incurred by public listed companies in Sri Lanka. Three variables were used as proxies for board of directors' diversity, which are the percentage of females on the board, a dichotomous dummy, and the Blau index. After controlling for size, industry, and other aspects of corporate administration, the study found a significantly negative relationship between the ratio of female directors and firm value as well as the increase in agency cost of companies. This evidence provides an insight for the government and academic institutions in their effort to provide resources that will assist to increase women's leadership skills. 
Apart from that, from the agency perspective, Adams et al. (2009) found that female directors could reduce the agency conflict because they are always being monitored by the senior directors as compared to their male colleagues. Jurkus et al. (2008) obtained the same result and explained the inverse relationship between the percentage of female directors and free cash flow as the proxy for agency cost. Therefore, a higher degree of gender diversity among the board of directors would increase the monitoring of the board of directors and decrease the information asymmetry.

Meanwhile, Carter et al. (2003) examined gender diversity and firm value in the context of agency theory and found a significant negative relationship between a small number of females on the board and agency cost of the firm for the Fortune 100 firms. They suggested that gender diversity could increase managerial monitoring and control as well as enhance board of directors' independence. The reason is that females may tend to ask questions that would not be asked by the male directors.

\section{The agency theory and the gender theory}

This study used three theories, namely the agency theory, Hofstede's cultural dimension theory, and resource dependency theory. The agency theory, which was introduced by Jensen and Meckling (1976) and Myers (1984), suggested that the separation of ownership and control in modern companies could lead to various conflicts from several sources. As an example, the separation of ownership from control in large public companies could cause conflicts between the creditors and the firm and between the managers and the shareholders. Heath (2009) emphasised that the agency theory establishes the responsibility of the principle and the duty of the agent to safeguard their interests as well as possible. The principle's interest is to maximise profits and share price, and the agent has to work towards achieving this goal. However, this creates a form of agency problem when the directors have the intention to maximise their personal utility by taking steps that could benefit them at the expense of the shareholders (Tricker, 2000).

The cultural dimension theory was established based on the research that was mostly conducted by Professor Geert Hofstede, Gert Jan Hofstede, Michael Minkov, and their research team. Hofstede had analysed the cultures of several countries and combined them in six dimensions. The six cultural dimensions built by Hofstede and several other researchers are power distance, uncertainty avoidance, individualism versus collectivism, masculinity versus femininity, long-term versus short-term orientation, and indulgence versus restraint. According to Porter, Samover, and McDaniel (2007), Hofstede used the word masculinity and femininity to refer to the extent that the masculinity and femininity characteristics are appreciated and highlighted in a particular country. Masculine or feminine nature plays a big role in carrying out one's responsibility in an organisation. Masculinity is known as a dominant value in the society based on masculinity values such as competition, resolution, as well as accumulation of wealth and assets. Meanwhile, femininity refers to taking care of the welfare of others and giving priority to a balanced quality of life.

Besides, Jonas (2015) stated that the resource dependency theory is commonly used in the study of the effect of gender diversity towards the financial performance of the firm. This theory suggests that the firm is an open system that has an inter-dependent relationship with external entities and that the success of the organisation depends on the relationship and the entities (Pfeffer \& Salancik, 1978). Moreover, according to Jonas (2015), various aspects will emerge when the resource dependency theory is applied in the study of the implication 
of gender diversity on the board of directors. One of these aspects is that female directors bring in different and valuable resources to the board. According to Terjesen et al. (2009), female directors bring their knowledge, skills, and experience to the board that are different from their male colleagues.

\section{Mechanisms for Corporate Governance}

Corporate governance is one of the control keys in managing company's operation (Fama 1980; Fama \& Jensen 1983). Previous researches by western researchers, like (Anderson and eeb, 2003; Miller and Breton-Miller, 2006 and Villalonga dan Amit, 2006) and those by local's (Amran \& Ahmad, 2009; Samad et. al., 2008) suggesting that the relationship between the corporate governance mechanism and agency cost producing mixed findings. One of the important criteria of corporate governance is the size of board directors. It plays important role in taking responsibility disciplining the management to reduce the agency cost. The size of board directors found to be different between countries due to the differences in culture. Lipton and Lorsch (1992) are suggesting that the board should be limited to 7 or 8 members. This statement also supported by Eisenberg, Sundgren dan Wells (1998), where they firmly outlined that the difficulty in communication will occur as the members increases. The agency will meet more problems thus increasing the agency cost.

Agency theory also suggests that the duality of chief executive officer (CEO) would bring to the management domination and produce a weak performance (Shleifer and Vishny, 1997). The CEO duality also encourages and allows the power abuse to happen (Jensen, 1993). According to Belkhir (2004), this separation will help to cut the agency cost and increasing the firm's performance. This can happen when the CEO who is also the board's chairman, the authority of the firm will also be controlled by the same person. Important information could be controlled from being informed to the members of the board, thus taking advantage to abuse the power given. As for researchers like Brickley et. al., (1997) and Dahya et. al, (1996), they stated that CEO duality role is very important to decrease misunderstanding and argument in discussing ideas and opinions. Decision making process could be done in time without further delay.

Researches in economic and financial management nowadays are focusing on board of directors' composition to gain information about the company's performance. The independence of the board is always assumed to be the main encouragement of good and efficient corporate governance. The focus on independent directors was based on the agency theory (Fama and Jensen, 1983). The agency theory suggests that non-executive director is needed in the board of directors to monitor and control the executive directors from their opportunist act (Jensen and Meckling, 1976; and Lynall, et. al., 2003).

Few researchers reported that the size of audit committee was the most influential factor for effective work in an organization. The committee size was said to be the criteria that was relevant to the effectiveness of job execution (Cadbury committee, 1992). Al-Mahamid and Al -Sa'eed, (2011), Bédard, Chtourou and Courteau, (2004) outlined that 
the bigger the number of members in audit committee, the tighter the controlling and monitoring towards the finance account function and process will be. The big size of the audit committee has the potential to recovering and controlling the accounting and financing process much more effectively as stated by Anderson et. al. (2004).

Besides that, an audit committee with frequent meeting often has more time to supervise the financial report process, identify risk management and monitor the internal control. As the result, the firm agency cost will be reduced. Zhou and Chen (2004) suggested that the audit committee meeting will act as the vital mechanism to improve and encourage the corporate governance in the company. Al-Mamun, et. al. (2014) also stated in their research that a frequently held audit committee meeting could help reduce the agency problems and asymmetry of information between the agents and principal, where fair and precise information will be delivered to the investors on time.

Moreover, the audit quality service has a vital role to reduce the asymmetry information and the agency problem caused by the separation of ownership and control in a firm (Willenborg, 1999). Therefore, the external auditor could contribute to the corporate governance's efforts to reduce the agency problem between the manager and the shareholders. The bigger the conflict, the bigger the agency cost thus the request for the audit quality will increase (Palmrose 1986; Francis and Wilson 1988; De Fond 1992; Craswell, Francis and Taylor, 1995). With the assumption that the audit quality will see a reduction in the agency cost and the auditors also showing the credibility of the finance statement information that can be trusted, the monitoring cost will be lowered and increased the company performance.

\section{METHODOLOGY}

This study is conducted to examine the relationship between female directors on the board and agency cost for companies that were listed on Bursa Malaysia in the Trading and Services sector. The study covers the internal mechanisms, namely the board of directors (CEO duality, independent directors, and board size) and the audit committee (audit committee meetings and size of the audit committee). Meanwhile, audit quality serves as the external mechanism. The population in this research involves the firms that are listed at Bursa Malaysia in 2010 until 2013. The sample of the research is 150 companies in trade and service sector. In this study, data will be gathered from the financial information in the annual reports of the selected companies in the Trading and Services sector for companies that were listed on Bursa Malaysia from 2010 until 2013. Consequently, the annual reports that will be used in this study comprise the secondary data.

The agency cost will be measured using the asset utilisation ratio and the expense ratio. The asset utilisation ratio is the year's sales that is divided with the total asset. The ratio measure the company's management effectiveness to use and arrange their asset. The company that face low asset utilisation ratio showing a large cost of agency, meaning that there are negative relation between each other (Ibrahim and Samad, 2011). This agency costs proxy was acceptable by Florackis and Ozkan (2004), Singh and Davidson (2003) and Ang et al. (2000). Next, the expense ratio is measured by the operation expenses divided by the year's sale. This research used the agency cost proxy as used by Ang and Ding (2005) and 
Ang et al. (2000). This ratio measure how far is the effectiveness of the company's management to control operation cost such as luxury car expenses or company's furniture and others direct agency costs. Differ from the asset utilisation ratio, the agency cost always positive when it comes to the expenses ratio.

All data that will be obtained and gathered will be analysed using the descriptive statistics, pearson correlation, and linear regression. Finally, this study is developed as an empirical study of the companies that were listed on Bursa Malaysia with the aim of measuring the agency cost of the companies by using the agency cost development model.

The model that has been developed is as follows:

$$
\begin{aligned}
& \text { Agency cost }=\alpha+\beta_{1}(\text { PERFEMALEBOD })+\beta_{2}(\text { BODSIZE })+\beta_{3} \\
& (\text { DUAL })+\beta_{4}\left(\text { PERBODIND) }+\beta_{5}(\text { ACSIZE })+\beta_{6}(\text { ACMEET })+\beta_{7}\right. \\
& \left(\text { BIG4) }+\beta_{8}(\text { FMSIZE })+\beta_{9}(\text { LEV })+\varepsilon\right.
\end{aligned}
$$

where,

PERFEMALEBOD = percentage number of female directors in total directors;

BODSIZE $=$ number of members held in board;

DUAL $=$ if the CEO is a chairman, it is valued at one otherwise 0;

PERBODIND = percentage of independent directors on the number of directors;

ACSIZE $=$ total number of audit committee members;

ACMEET $=$ it at least four times audit committee meetings within a year it is valued at one otherwise 0 ;

BIG4 = if firm is audited by Big4 it is valued at one otherwise 0;

FMSIZE = total assets held by the firm;

$\mathrm{LEV}=$ percentage of total debt to total assets.

\section{FINDINGS OF THE STUDY}

Table 1 shows the summary of the descriptive statistics for the main variable that was used in this study for the listed companies in the Trading and Services sector on Bursa Malaysia in the four years from 2010 to 2013. Based on the data analysis in Table 1, the average value of the agency cost in this study based on asset utilisation ratio (AUR) is 0.574 , with the maximum and minimum value of 2.130 and 0.058 , respectively. Meanwhile, the average value of the agency cost in this study based on expense ratio (ER) is 0.245 , with the maximum and minimum value of 1.450 and 0.012 , respectively. Other than that, the average value for the firm size (FMSIZE) is 0.078, whilst the maximum and minimum value are 3.9994 and -1.925 respectively, with standard deviation is 0.301 . The same goes to average value of leverage (LEV) that gets 0.419 , with the maximum and minimum value are 1.849 and 0.00 , respectively with standard deviation of 0.221 .

According to Table 1, the average level for the female board director (PERFEMALEBOD) is $64 \%$ with standard deviation of 0.809 . For the second variable that 
is an independent director (PERBODIND), shows an average percentage of $45 \%$ with $0 \%$ for the minimum value and up to $80 \%$ maximum value. The standard deviation is $0.12 \%$. The findings suggesting that the listed companies are all obeying to the advices made by MCCG (2010) where 1/3 of the board should be independent. However, the findings also showing few companies in the sample do not have an independent director although the SEC (2006) rules already asked at least 1/10 from the minimum number of the board should be independent.

Table 1: Descriptive statistics

\begin{tabular}{lrrrr}
\hline \multicolumn{1}{c}{ Variable } & Minimum & Maximum & Average & $\begin{array}{c}\text { Standard } \\
\text { Deviation }\end{array}$ \\
\hline PERFEMALEBOD & 0 & 3 & 0.64 & 0.809 \\
PERBODIND & 0.000 & 0.800 & 0.449 & 0.166 \\
BODSIZE & 4 & 15 & 7.540 & 2.023 \\
DUAL & 0.000 & 1.000 & 0.358 & 0.206 \\
ACMEET & 1 & 21 & 5.270 & 1.657 \\
ACSIZE & 2 & 6 & 3.300 & 0.578 \\
BIG4 & 0 & 1 & 0.530 & 0.500 \\
FMSIZE & -1.925 & 3.994 & 0.078 & 0.301 \\
LEV & 0.000 & 1.849 & 0.419 & 0.221 \\
AUR & 0.058 & 2.130 & 0.574 & 0.316 \\
ER & 0.012 & 1.450 & 0.245 & 0.205 \\
\hline
\end{tabular}

The next variable is the size of board director. The findings shows that the companies in the sample have 4 to 15 members of the board, meaning that a 7.54 average with 2.023 standard deviation. This can be concluded that the companies in the sample consist of at least 8 members of board of director. The next variable is the audit committee meeting (ACMEET). The findings show that the average meeting that was held is 5 times a year. It is found that there are companies who only held the meeting once in a year, where that is the minimum value and the highest number of meeting as the maximum value of this variable is 21 times. This is proving that the samples involved, are fulfilling the corporate governance codes, which stated that the audit committee should at least held a meeting for every quarter of the year or in other words, 4 times a year.

Another variable is the CEO duality (DUAL). The findings shows (DUAL) received an average percentage of $36 \%$ between $0 \%$ of minimum value to $100 \%$ of the maximum value, with the standard deviation of $21 \%$. This can conclude that few companies practicing 
the separation between CEO and the company chairperson. The last variable is audit quality (BIG4). The findings shows an average of 53\% of the companies in the sample audit their company financial account using the service of auditors from audit firm (BIG4) that comply to the statutory accountant institute in Malaysia. The standard deviation is 0.50 .

Table 2 shows the result of the Pearson Correlation for the independent variables, dependent variable, and control variable that were analysed by using the SPSS analysis. The findings of the study show that the highest coefficient value is 0.616 , which is between independent directors (PERBODIND) and board size (BODSIZE). It means that the strength of the relation between the two variables is $61.6 \%$. In conclusion, the number of the independent directors increases in conjunction with the number of boards of directors in the company.

Table 3 shows the result of regression test for the independent variables and dependent variable, namely the percentage of female directors (PERFEMALEBOD), board size (BODSIZE), CEO duality (DUAL), the percentage of independent directors (PERBODIND), the size of the audit committee (ACSIZE), audit committee meetings (ACMEET), audit quality (BIG4), company size (FMSIZE), and leverage (LEV) with asset utilisation ratio (AUR). Regression analysis has been conducted to assess the influence of female directors on agency cost. The findings of this study show that female directors, board size, CEO duality, independent directors, and audit quality have a significantly negative relationship with agency cost by using asset utilisation ratio (AUR) as the proxy. As the relation between AUR and agency cost is negative, it shows that the larger number of female boards directors, size of board directors, CEO duality, independent directors and audit quality in a company, it will increase the agency cost.

Subsequently, Table 4 shows the results of the regression test for the independent variables and dependent variable, namely the percentage of female directors (PERFEMALEBOD), board size (BODSIZE), CEO duality (DUAL), the percentage of independent directors (PERBODIND), the size of the audit committee (ACSIZE), audit committee meetings (ACMEET), audit quality (BIG4), company size (FMSIZE), and leverage (LEV) with expense ratio (ER). Using expense ratio as the proxy (ER), the findings of the study show that female directors, the size of the audit committee, and audit quality have a significantly negative relationship with agency cost.

According to the findings of the research, an improvement to the number of female board directors, size of audit committee and audit quality in an organization will cause the expenses ratio (ER) to decrease, thus decreasing the agency cost. Meanwhile, the board size, CEO duality, independent boards and audit committee meeting show a positive significant relationship with the agency cost. 
Table 2: Pearson Correlation

\begin{tabular}{|c|c|c|c|c|c|c|c|c|c|c|c|c|}
\hline & $\begin{array}{l}\text { Independent } \\
\text { Variable }\end{array}$ & 1 & 2 & 3 & 4 & 5 & 6 & 7 & 8 & 9 & 10 & 11 \\
\hline 1 & Perfemalebod & 1.000 & & & & & & & & & & \\
\hline 2 & Bodsize & $0.244 * *$ & 1.000 & & & & & & & & & \\
\hline 3 & Dual & 0.045 & $0.208 * *$ & 1.000 & & & & & & & & \\
\hline 4 & Perbodind & $0.111 * *$ & $0.616 * *$ & $0.329 * *$ & 1.000 & & & & & & & \\
\hline 5 & Acsize & $0.082^{*}$ & $0.409 * *$ & $0.286 * *$ & $0.428 * *$ & 1.000 & & & & & & \\
\hline 6 & Acmeet & $0.096^{*}$ & $0.215^{* *}$ & $0.497 * *$ & $0.316^{* *}$ & $0.238 * *$ & 1.000 & & & & & \\
\hline 7 & Big4 & $0.115^{* *}$ & $0.234 * *$ & $0.116^{* *}$ & $0.210 * *$ & $0.226 * *$ & $0.110 * *$ & 1.000 & & & & \\
\hline 8 & Fmsize & 0.071 & $0.112 * *$ & 0.008 & 0.018 & -0.030 & 0.019 & -0.012 & 1.000 & & & \\
\hline 9 & Lev & 0.013 & -0.005 & 0.029 & -0.004 & -0.056 & 0.042 & $0.096^{*}$ & $0.154 * *$ & 1.000 & & \\
\hline 10 & AUR & $0.172 * *$ & 0.018 & -0.042 & -0.067 & 0.033 & 0.004 & -0.073 & -0.051 & -0.133 & 1.000 & \\
\hline 11 & ER & 0.037 & $0.094 *$ & $0.199 * *$ & $0.163 * *$ & 0.015 & $0.162 * *$ & -0.047 & -0.055 & -0.076 & $-0.191 * *$ & 1.000 \\
\hline
\end{tabular}

** Significant value of 0.01

* Significant value of 0.05 
Table 3: Linear regression (AUR)

\begin{tabular}{|c|c|c|c|c|}
\hline Variable & & Beta & $\mathbf{t}$ & Sig. \\
\hline Perfemalebod & & -0.181 & $4.379 *$ & 0.000 \\
\hline Bodsize & & -0.056 & $-1.857 * *$ & 0.003 \\
\hline Dual & & -0.032 & $-0.640^{*}$ & 0.022 \\
\hline Perbodind & & -0.123 & $-2.277 *$ & 0.023 \\
\hline Acsize & & 0.064 & $1.389^{*}$ & 0.165 \\
\hline Acmeet & & 0.014 & $0.282 *$ & 0.778 \\
\hline Big4 & & -0.083 & $1.975^{*}$ & 0.049 \\
\hline Fmsize & & -0.049 & $-1.204 *$ & 0.229 \\
\hline Lev & & -0.117 & $-2.858 * *$ & 0.004 \\
\hline Durbin Watson & 1.769 & & & \\
\hline R Square & 0.067 & & & \\
\hline Adj. R Square & 0.053 & & & \\
\hline $\mathrm{F}$ & 4.711 & & & \\
\hline
\end{tabular}

Table 4: Linear regression (ER)

\begin{tabular}{|c|c|c|c|c|}
\hline Variable & & Beta & $\mathbf{t}$ & Sig. \\
\hline Perfemalebod & & -0.199 & $-6.852 *$ & 0.000 \\
\hline Bodsize & & 0.100 & $0.513 *$ & 0.003 \\
\hline Dual & & 0.153 & $3.226^{*}$ & 0.001 \\
\hline Perbodind & & 0.133 & $2.456^{*}$ & 0.014 \\
\hline Acsize & & -0.098 & $-2.129 *$ & 0.034 \\
\hline Acmeet & & 0.070 & $1.506^{*}$ & 0.133 \\
\hline Big4 & & -0.087 & $-2.093 *$ & 0.037 \\
\hline Fmsize & & -0.069 & $-1.724 *$ & 0.005 \\
\hline Lev & & 0.117 & $2.858 *$ & 0.004 \\
\hline Durbin Watson & 1.974 & & & \\
\hline R Square & 0.074 & & & \\
\hline Adj. R Square & 0.061 & & & \\
\hline $\mathrm{F}$ & 5.801 & & & \\
\hline
\end{tabular}




\section{DISCUSSION}

The results of linear regression analysis indicate that the female board directors (PERFEMALEBOD) have a positive significant relationship with the asset utilisation ratio (AUR). As the AUR and the agency cost have an inverse relation, it means that when the percentage of female directors increase, the agency cost decreases. This would mean that the participation of the female cannot be underestimated as it is proven to reduce the firm agency cost. Whereas for the expenses ratio (ER) and the PERFEMALEBOD, the results depict that these variables have negative significant relationship with the agency cost. It is proven in the findings, that the total number of the female board of director in an organization will cause a reduction in ER, thus decreasing the agency cost. According to Adams et al. (2009), the female board of director will reduce the agency conflict as they are often monitored by the upper board of director compared to the males.

Next, the findings also show that the size of the board (BODSIZE) influences the agency cost and the coefficient value is negative following the asset usage ratio (AUR). Thus, it can be concluded that the BODSIZE influences and affects the agency cost measured by AUR. As the AUR and the agency cost have an inverse relationship, it implies that when the size of the board increases, the agency cost increases as well. While for the ER, BODSIZE resulted in a positive effect. These findings are consistent with Florackis and Ozkan (2004), who found that board size has a negative coefficient about the asset turnover, thus proving that the large size of board is ineffective (Beiner et al, 2004).

Other than that, the findings of the research show that the CEO duality (DUAL) has a relationship that is significant with the agency cost and the coefficient value is negative according to the AUR, and the coefficient is positive according to the ER. This is indicates that increased practice of CEO duality will lead to the reduction in the AUR and increase in the ER, thus the agency cost increase. The result of this research maybe caused by common practice in companies in Malaysia that used to the separation of the CEO and the company chairman. Due to this situation, the findings showing that the result is significant between the CEO duality and the agency cost.

Besides that, the findings of the research show that the independent board of directors (PERBODIND) influences the agency cost and the coefficient value is negative according to the AUR, while positive according to the ER. This means that increased number of the PERBODIND in an organization will cause AUR to reduce, while increasing the ER thus increase the agency cost in a company. The findings imply that, even with independent member, the shareholders are not convincing with the board to determine the efficiency and fair company performance in the effort to reduce the agency problem between them and management (Azeez, 2015). In conclusion, the independent directors are only acting as the passenger in the organization as they do not have efficient and complete role to change or monitor the opportunist management.

In addition, the findings of the linear regression analysis show the audit committee size (ACSIZE) does not have a significant relation with AUR. However, the ACSIZE indeed has a significant relationship with ER. This means that the size of audit committee influences the agency cost at negative coefficient value according to ER. The findings show that agency cost reduces as the size of the committee increases which also parallel to the findings from Talat and Mian (2013) and Ebrahim et al. (2012). Based on these findings, it can be concluded that the audit committee size that is large will provide huge fundamental knowledge as there will be numbers of bright opinion from many auditors in crucial 
decision-making process. As a result, the controlling and management process of the account and finance can be improved.

The next findings show that the audit committee meeting (ACMEET) do not have a significant relation to the agency cost according to the AUR and ER. This means, the audit committee meeting does not influence or affect the agency cost. This result is also consistent with the findings from Ebrahim, Faudziah and Abdullah (2014), Marwan et. al. (2014), and Nidhi dan Anil (2016) that suggest that the relationship of ACMEET and agency cost is not significant because of the increment in expenses faced by the company as the total number of meeting held increase.

Moreover, the audit quality (BIG4) has a significant relationship with AUR and the coefficient value is positive. The improvement in BIG4 is proven to cause the AUR to increase but the ER reduce, thus decreasing the ER in a company. Companies that are audited by the bigger size audit firm would obey the exposure conditions, following the account principles with acceptable in general compared to the ones audited by smaller size firm (Krishnan and Schauer, 2000). Inten, Radziah and Romlah (2004) stated that the audit by bigger firm is much more quality than the one by smaller firm due to the fact that bigger firm always occupied with greater ability, technical skills, experience and expertise in many fields.

\section{IMPLICATION}

The findings emerged from this research affect and impact directly and indirectly to many parties involves. One of them would be the corporate company. In general, they are the one who execute the corporate governance for the management and administration of the company continuously. With these findings and discussion, hopefully it will help the corporate company to understand better and much more thorough about the corporate governance. If this can be done, improving the understanding among the companies involved, they could eventually reduce their own agency cost.

In addition, the findings could be the guidance to the investors in evaluating whether the company has a quality and stable corporate governance system. It is important for the evaluation to be made as it will prove the direction of the usage and management of the capital invest in the future. These findings also benefit the government from the perspective of the ability to understand the mechanism of corporate governance implication in improving company performance. It also can guide and become a reference in establishing company policies or finance policies for reducing agency cost.

Every research that was conducted is contributing to enrich the literature in each field. These findings help to improve and increase the number of ideas and facts in corporate governance. It can be a guidance and reference for future researchers. Not only that, contribution in theoretical and model can help improve and enrich the field of corporate governance.

\section{CONCLUSION AND RECOMMENDATIONS}

As a conclusion, this study shows that female directors and board size have a significantly negative relationship with agency cost by using asset utilisation ratio (AUR) and expense ratio (ER) as the proxies. Therefore, in corporate governance, female directors 
are important element in controlling the agency cost of a company. Thus, a company needs charismatic directors with leadership capability to monitor the corporate governance aspect in the company managed by the directors.

Several research recommendations have been put forward for the use of future researchers. The first recommendation is to include various sectors instead of focusing on only one sector. The second recommendation is to extend the data coverage period up to 10 years. The final recommendation is that future researchers may consider collecting data directly from the companies involved rather than using secondary data from the website of Bursa Malaysia.

\section{References}

Adams, R. and Ferreira, D. (2009), "Female in the boardroom and their impact on governance and performance", Journal of Financial Economics, Vol. 94, pp. 291-309

Al-Mamun, A., Yasser, Q., Rahman, M., Wickramasinghe, A. and Nathan, T. (2014). Relationship between audit committee characteristics, external auditors and economic value added (EVA) of public listed firms in Malaysia. Corporate Ownership and Control, 12 (1, Continued - 9), 899-910.

Al-Mahamid, S. and Al-Sa'eed, M., A. (2010). The relationship between perceived usefulness, perceived ease of use, perceived information quality, and intention to use E-government. Journal of Theoretical and Applied Information Technology. 11. 30-44.

Ang, J., S.Rebel, A.Cole, \& Lin, J. W. (2000). Agency Costs and Ownership Structure. The Journal of Finance, LV(1), 81-106.

Anderson, R.C. and Reeb, D.M. (2004), "Board composition: balancing family influence in S\&P 500 firms”, Administrative Science Quarterly, Vol. 49, pp. 209-37.

Beiner, S., Drobetz, W., Schmid, F. \& Zimmermann, H. (2004). An integrated framework of corporate governance and firm valuation: Evidence from Switzerland. ECGI Paper $34 / 2004$.

Bedard, J., Chtourou, S. and Courteau, L. (2004). The effect of audit committee expertise, independence, and activity on aggressive earnings management, Auditing: A Journal of Practice \& Theory, 23(2), 13-35.

Belkhir, M. (2004) Board Structure, Ownership Structure, and Firm Performance: Evidence from Banking. Applied Financial Economics, Vol 19, No. 19, pp. 1581-1593.

Brickley, J.A., Coles, J.L. \& Terry, R.L. (1994). 'Outside directors and the adoption of poison pills', Journal of Financial Economics, 34: 371-390.

Carter, D. A., B. J. Simkins, dan W. G. Simpson. (2003). Corporate governance, board diversity, and firm value. The Financial Review 38 (1): 33-53.

Ebrahim, M. A., Abdullah K. A., Faudziah, H. (2014). “The Measurements of Firm Performance's Dimensions". Asian Journal of Finance \& Accounting, Vol. 6 No. 1, pp. 24-49 
Eisenberg, T., Sundgren, S. \& Wells, M. (1998). 'Larger board size and decreasing firm value in small firms', Journal of Financial Economics, 48: 35-54.

Fama, E. F., \& Jensen, M. C. (1983). Separation of ownership and control. Journal of Law and Economics, 26, 327-349.

Florackis, C. \& Ozkan A. (2004). Agency Costs And Corporate Governance Mechanisms: Evidence For UK Firms. Working Paper, University of York, UK.

Heath, J. (2009). The uses \& abuses of agency theory. Business Ethics Quarterly, 4, 497-528.

Ibrahim, H., dan Samad, F. A. (2011). Agency costs, corporate governance mechanisms and performance of public listed family firms in Malaysia. Journal of Business Management, Vol. 42, No. 3, pp. 17-25.

Inten Meutia, and Radziah Abd Latiff, and Romlah Jaffar. (2004). Kebebasan juru audit sebagai pemoderat dalam hubungan antara kualiti audit dengan pengurusan perolehan. Jurnal Pengurusan, 23 . pp. 73-95

Jensen, M., \& Meckling, W. (1976). Theory of the firm: Managerial behavior, agency costs and ownership structure. Journal of Financial Economics, 3(4), 305-360.

Jonas, M. (2015). Oppose, Support, or Hedge? Distributional Effects, Regulatory Pressure, and Business Strategy in Environmental Politics. Global Environmental Politics 15(2): 19-37.

Jurkus, A. F., Park, J. C., \& Woodard, L. S. (2008). Gender diversity, firm performance, and environment. Working Paper. Obtained on 1 Mac 2015 from http://ssrn.com/abstract=1085109.

Larkin, M. B., Bernardi, R. A. dan Bosco, S. M. (2013), Does female representation on Boards of Direcors associate with increased transparency and ethical behavior?", Accounting and the Public Interest, Vol. 13, pp. 132-150.

Lynall, M. D., Golden, B. R., \& Hillman, A. J. (2003). Board composition from adolescence to maturity: A multitheoretic view. Academy of Management Review, 28(3), 416-431.

Myers, S.C (1984), “The Capital Structure Puzzle”, Journal of Finance, Vol. 39, pp. 575-92.

Nirosha H. W., \& Stuart L. (2013). Female on Board, Firm Financial Performance and Agency Costs. Asian Journal of Business Ethics, Volume 2, Issue 2, pp. 113-127.

Pfeffer, J. dan Salancik, G. R. (1978). The External Control of Organizations: A Resource Dependence Perspective, Harper \& Row, New York.

Porter, R., Samovar, L., McDaniel, E. (2007). Communication Between Cultures. Cengage Learning, Di peroleh pada 3 November 2017, daripada https://books.google.com.my/books?id=dQfuf05kheYC

Singh, M., \& Davidson, W. N. (2003). Agency costs, ownership structure and corporate governance mechanisms. Journal of Banking and Finance, 27, 793-816. 
Shleifer, A. and Vishny, R. W. (1986). A survey of corporate governance. Journal of Finance, 52, 737-783.

Terjesen, S., \& Singh, V. (2009). Female presence on corporate boards: A multi-country study of environmental context. Journal of Business Ethics, 83(1), 55-63

Thiruvadi, S., \& Huang, H.-W. (2011). Audit committee gender differences and earnings management. Gender in Management: An International Journal, 26(7), 483-498.

Tricker, B. (2000). Editorial-corporate governance-the subject whose time has come. Corporate Governance, 4, 289-296. 